\title{
Infection with Anaplasma phagocytophilum in a seronegative patient in Sicily, Italy: Case Report
}

\author{
J de la Fuente*1,2, A Torina3 ${ }^{3}$ V Naranjo², S Caracappa3 , V Di Marco4, \\ A Alongi $^{3}$, M Russo ${ }^{4}$, AR Maggio ${ }^{3}$ and KM Kocan ${ }^{1}$
}

\author{
Address: ${ }^{1}$ Department of Veterinary Pathobiology, Center for Veterinary Health Sciences, Oklahoma State University, Stillwater, OK 74078, USA, \\ ${ }^{2}$ Instituto de Investigación en Recursos Cinegéticos IREC (CSIC-UCLM-JCCM), Ronda de Toledo s/n, 13005 Ciudad Real, Spain, ${ }^{3}$ Intituto \\ Zooprofilattico Sperimentale della Sicilia, Via G. Marinuzzi n ${ }^{\circ}$ 3, 90129 Palermo, Italy and ${ }^{4}$ Istituto Zooprofilattico Sperimentale della Sicilia, Area \\ Barcellona Pozzo di Gotto, Via S. Andrea ${ }^{\circ}$ 96, 98051 Barcellona, Italy \\ Email: J de la Fuente* - djose@cvm.okstate.edu; A Torina - torina@pa.izs.it; V Naranjo - MVictoria.Naranjo@uclm.es; \\ S Caracappa - caracappa@pa.izs.it; V Di Marco - dimarco@pa.izs.it; A Alongi - alongi@pa.izs.it; M Russo - russo@pa.izs.it; \\ AR Maggio - maggio@pa.izs.it; KM Kocan - kmk285@cvm.okstate.edu \\ * Corresponding author
}

\section{Published: 03 October 2005}

Annals of Clinical Microbiology and Antimicrobials 2005, 4:15 doi:I0.1 I86/1476-07| I-4-15

This article is available from: http://www.ann-clinmicrob.com/content/4/I/I5

(C) 2005 de la Fuente et al; licensee BioMed Central Ltd.

This is an Open Access article distributed under the terms of the Creative Commons Attribution License (http://creativecommons.org/licenses/by/2.0), which permits unrestricted use, distribution, and reproduction in any medium, provided the original work is properly cited.
Received: 10 August 2005

Accepted: 03 October 2005

\begin{abstract}
Background: Anaplasma phagocytophilum causes human granulocytic anaplasmosis (HGA) in humans, which has been recognized as an emerging tick-borne disease in the United States and Europe. Although about 65 cases of HGA have been reported in Europe, some of them do not fulfill the criteria for confirmed HGA. Confirmation of HGA requires $A$. phagocytophilum isolation from blood, and/or identification of morulae in granulocytes and/or positive PCR results with subsequent sequencing of the amplicons to demonstrate specific rickettsial DNA. Seroconversion or at least fourfold increase in antibody titers to $A$. phagocytophilum has been used as criteria for confirmed HGA also.

Case presentation: Infection with A. phagocytophilum was confirmed by PCR in a patient in Sicily, Italy, who had negative serology for A. phagocytophilum. A fragment of A. phagocytophilum I6S rDNA was amplified by two independent laboratories and sequenced from two separate patient's blood samples. The $16 \mathrm{~S}$ rDNA sequence was identical in both samples and identical to the sequence of the $A$. phagocytophilum strain USG3 originally obtained from a dog.

Conclusion: Infection with A. phagocytophilum was confirmed in a patient without a detectable antibody response against the pathogen. The results reported herein documented the first case of confirmed HGA in Sicily, Italy. These results suggested the possibility of human infections with $A$. phagocytophilum strains that result in clinical symptoms and laboratory findings confirmatory of HGA but without detectable antibodies against the pathogen.
\end{abstract}

\section{Background}

Anaplasma phagocytophilum (Rickettsiales: Anaplasmata- ceae) causes human granulocytic anaplasmosis (HGA) in humans, which has been recognized as an emerging tick- 
borne disease in the United States and Europe [1,2]. The disease was first described in the United States in 1994 [3,4] and in Slovenia in 1997 [5]. About 65 cases have been reported in Europe although some of them do not fulfill the criteria for confirmed or probable HGA [2]. Human infection with $A$. phagocytophilum could be confirmed by identification of morulae in granulocytes, positive PCR results using whole blood as a substrate, and/or isolation of A. phagocytophilum from the blood [2]. Serological tests, particularly indirect immunofluorescence assay (IFA), are commonly used but are often negative during the initial phase of the disease. However, high and stable antibody titers to A. phagocytophilum are usually found in patients with probable HGA who show clinical signs and symptoms that most likely are not the result of a recent infection with $A$. phagocytophilum [2].

Although the seroprevalence of HGA in central and southern Italy is high in workers at risk for tick bites [6], only two cases of HGA have been reported in Italy [7]. However, the analysis of A. phagocytophilum DNA was not performed in these cases. The objective of this study was to characterize the 16S rDNA sequence of a strain of $A$. phagocytophilum obtained from a seronegative patient with confirmed HGA in Sicily, Italy.

\section{Case Presentation \\ Patient, materials and methods}

On May 8, 2004, a 51-year-old man living in Barcellona Pozzo di Gotto, Messina, Sicily, Italy was admitted to the hospital with a 3-month fever $\left(37.2^{\circ} \mathrm{C}\right)$, arthralgia, myalgia, malaise, pallor, stiffnes of hands and knee, nausea, low appetite and weight loss. The patient did not recall a tick bite but he visited hunting areas 15 days before the fever started and kept exotic birds (golden pheasants, partridges and guinea fowls) at his house for two years. The patient showed abnormal liver (462 mU/ml alkaline phosphatase, normal range $(\mathrm{nr})=98-280 ; 1.20 \mathrm{mg} / \mathrm{dl}$ total bilirubin, $\mathrm{nr}=0.16-1.10 ; 0.35 \mathrm{mg} / \mathrm{dl}$ direct bilirubin, $\mathrm{nr}=0.0-0.2)$ and renal $(1.5 \mathrm{mg} / \mathrm{dl}$ creatinine, $\mathrm{nr}=0.5-1.2)$ functions and low hemoglobin $(9.9 \mathrm{~g} / \mathrm{dl} ; \mathrm{nr}$ $=12-18)$. Pulmonary, cardiac and immunological involvement was absent. Cell counts and serum C-reactive protein levels were normal.

On September 13, 2004 the patient was admitted to the hospital for a second time. In addition to previous findings, the patient showed a mild splenomegaly, hemorrhoids, osteopenia, hiatal hernia, gastritis and inflammation of duodenum. Systemic inflammatory pathology and neoplasia were ruled out. Doctors suspected a depressive syndrome and the patient was treated with antidepressants.
Serum antibodies were determined for Lyme borreliosis, Rickettsia conorii, Coxiella burnetii and A. phagocytophilum (Fuller Laboratories, Fullerton, CA, USA), and Ehrlichia chaffeensis and A. phagocytophilum (Focus Technologies, Cypress, CA, USA) following manufacturer's recommendations. FITC-conjugated anti-human IgG (Sigma, St. Louis, MO, USA) and IgM (Aliphadia S.A., Wavre, Belgium) were used as secondary antibodies. The immunofluorescence tests for $A$. phagocytophilum use antigens derived from human HL-60 cells infected with the HGE-1 isolate and samples were considered negative when no fluoresce was detected at 1:80 (Fuller Laboratories) or 1:64 (Focus Technologies) dilution of the test serum, as recommended by the manufacturer. DNA was purified using GenElute Mammalian Genomic DNA Miniprep Kit (Sigma) or TriReagent (Sigma) from patient's blood samples collected in September 8 and October 8, 2004. PCR analysis for R. conorii, C. burnetii, E. chaffeensis, Theileria spp., Babesia spp. and Anaplasma spp. were conducted on both DNA samples as previously described [8-11]. PCRs were conducted with $1 \mu \mathrm{l}(0.1-10 \mathrm{ng})$ DNA using $10 \mathrm{pmol}$ of each primer in a $50-\mu$ l volume $\left(1.5 \mathrm{mM} \mathrm{MgSO}_{4}, 0.2\right.$ $\mathrm{mM}$ dNTP, $1 \times$ AMV/Tfl $5 \times$ reaction buffer, $5 \mathrm{u}$ Tfl DNA polymerase) employing the Access RT-PCR system (Promega, Madison, WI, USA). Reactions were performed in an automated DNA thermal cycler for 35 cycles. PCR products were electrophoresed on 1\% agarose gels to check the size of amplified fragments by comparison to a DNA molecular weight marker (1 Kb DNA Ladder, Promega). Control reactions were done without the addition of DNA to rule out contaminations during PCR.

Amplified Anaplasma 16S rDNA fragments were resin purified (Wizard, Promega) and cloned into pGEM-T vector (Promega) for sequencing both strands by doublestranded dye-termination cycle sequencing (Core Sequencing Facility, Department of Biochemistry and Molecular Biology, Noble Research Center, Oklahoma State University). Two independent clones were sequenced from each PCR. Multiple sequence alignment was performed with the program AlignX (Vector NTI Suite, version 5.5; InforMax, North Bethesda, MD, USA).

\section{Results and discussion}

The analysis of the clinical symptoms and laboratory results of the patient described herein suggested the possibility of an infectious agent as the cause of the illness. Viral infections were ruled out and the investigation was directed towards the identification of tick-borne pathogens.

Serology for Lyme borreliosis, R. conorii, C. burnetii, E. chaffeensis and HGA and PCR analyses for R. conorii, C. burnetii, E. chaffeensis, Theileria spp. and Babesia spp. were negative. However, positive PCR results were obtained for 
Anaplasma spp. in patient's blood samples collected in September 8 and October 8, 2004. PCR reactions for Anaplasma spp. 16S rDNA were conducted with independent DNA extractions in two laboratories (in Palermo, Sicily and in Ciudad Real, Spain) to confirm the results. Control reactions ruled out PCR contaminations and the sequence of the 16S rDNA fragment obtained from the patient (Genbank accession number DQ029028) was identical in both DNA samples and identical to the sequence of the $A$. phagocytophilum strain USG3 originally obtained from a dog (Genbank accession number AY055469; ref. [12]).

The patient described herein fulfilled the criteria for confirmed HGA, including prolonged fever, arthralgia, myalgia, malaise, nausea, abnormal liver function and positive PCR and sequence analysis for A. phagocytophilum DNA. However, the patient was seronegative for up to six months after detection of pathogen infection by PCR. These results suggested that the patient presented a chronic stage of infection with symptoms produced by a secondary illness related or not to A. phagocytophilum and/ or could has been infected with a strain of the pathogen that could not be detected by existing serological tests or induces a low antibody response. Strain genetic differences have been reported in A. phagocytophilum and may be associated with variations in pathogenicity and host tropism [10,12-14], although the exact relationship between these factors is presently unknown.

\section{Conclusion}

The results reported herein demonstrated a prolonged $A$. phagocytophilum infection in a patient without a detectable antibody response against the pathogen. These results documented the first case of prolonged A. phagocytophilum infection in Sicily, Italy and suggest the possibility of human infections with $A$. phagocytophilum strains that result in clinical symptoms and laboratory findings confirmatory of HGA but without detectable antibodies against the pathogen.

\section{Authors' contributions}

JF carried out the sequence analysis, designed the study and drafted the manuscript. AT and SC conceived the study, and participated in its design and coordination and helped to draft the manuscript. VN and AA carried out the molecular genetic studies. VDM and MR collected and analyzed the clinical data. ARM carried out the immunoassays. KMK helped to draft the manuscript. All authors read and approved the final manuscript.

\section{Acknowledgements}

This research was supported by The Ministry of Health, Italy, the Instituto de Ciencias de la Salud (ICS-JCCM), Spain (project 03052-00) and the Endowed Chair for Food Animal Research and the Oklahoma Agricultural Experiment Station Project 1669 (K.M. Kocan). V. Naranjo is funded by Junta de Comunidades de Castilla - La Mancha (JCCM), Spain. We thank S.
Scimeca, R. D'Agostino and A. Corrente (Intituto Zooprofilattico Sperimentale della Sicilia, Palermo, Italy) for technical assistance.

\section{References}

I. Bakken JS, Dumler JS: Human granulocytic ehrlichiosis. Clin Infect Dis 2000, 31 : 554-560.

2. Lotric-Furlan S, Petrovec M, Avsic-Zupanc T, Strle F: Comparison of patients fulfilling criteria for confirmed and probable human granulocytic ehrlichiosis. Scand J Infect Dis 2004, 36:817-822.

3. Bakken JS, Dumler JS, Chen S-M, Eckman MR, Van Etta LL, Walker $\mathrm{DH}$ : Human granulocytic ehrlichiosis in the upper Midwest United States, a new species emerging? JAMA 1994, 272:212-218.

4. Chen S-M, Dumler JS, Bakken JS, Walker DH: Identification of a granulocytotropic ehrlichia species as the etiologic agent of human diseases. J Clin Microbiol 1994, 32:589-595.

5. Petrovec M, Lotric Furlan S, Zupanc TA, Strle F, Brouqui P, Roux V, Dumler JS: Human disease in Europe caused by a granulocytic Ehrlichia species. J Clin Microbiol 1997, 35: 1556-1559.

6. Santino I, Cammarata E, Franco S, Galdiero F, Oliva B, Sessa R, Cipriani $P$, Tempera G, Del Piano M: Multicentric study of seroprevalence of Borrelia burgdorferi and Anaplasma phagocytophila in high-risk groups in regions of central and southern Italy. Int J Immunopathol Pharmacol 2004, 17:219-223.

7. Ruscio $M$, Cinco $M$ : Human granulocytic ehrlichiosis in Italy: first report on two confirmed cases. Ann NY Acad Sci 2003, 990:350-352.

8. Tzianabos T, Anderson BE, McDade JE: Detection of Rickettsia rickettsii DNA in clinical specimens by using polymerase chain reaction technology. J Clin Microbiol 1989, 27:2866-2868.

9. To $H$, Kako N, Zhang GQ, Otsuka H, Ogawa M, Ochiai O, Nguyen SV, Yamaguchi T, Fukushi H, Nagaoka N, Akiyama M, Amano K, Hirai $\mathrm{K}: \mathbf{Q}$ fever pneumonia in children in Japan. J Clin Microbiol 1996, 34:647-65I.

10. Stuen S, Nevland S, Moum T: Fatal cases of Tick-borne fever (TBF) in sheep caused by several I6S rRNA gene variants of Anaplasma phagocytophilum. Ann NY Acad Sci 2003, 990:433-434.

II. de la Fuente J, Naranjo V, Ruiz-Fons F, Vicente J, Estrada-Peña A, Almazán C, Kocan KM, Martín MP, Gortázar C: Prevalence of tickborne pathogens in ixodid ticks (Acari: Ixodidae) collected from European wild boar (Sus scrofa) and Iberian red deer (Cervus elaphus hispanicus) in central Spain. EurJ Wild Res 2004, 50:187-196.

12. Massung RF, Lee K, Mauel M, Gusa A: Characterization of the rRNA genes of Ehrlichia chaffeensis and Anaplasma phagocytophila. DNA Cell Biol 2002, $21: 587-596$.

13. Massung RF, Priestley RA, Miller NJ, Mather TN, Levin ML: Inability of a variant strain of Anaplasma phagocytophilum to infect mice. J Infect Dis 2003, I88: 1757-I763.

14. de la Fuente J, Massung RF, Wong SJ, Chu FK, Lutz H, Meli M, von Loewenich FD, Grzeszczuk A, Torina A, Caracappa S, Mangold AJ, Naranjo V, Stuen S, Kocan KM: Sequence analysis of the msp4 gene of Anaplasma phagocytophilum strains. J Clin Microbiol 2005, 43: I309-1317.

Publish with Bio Med Central and every scientist can read your work free of charge

"BioMed Central will be the most significant development for disseminating the results of biomedical research in our lifetime. "

Sir Paul Nurse, Cancer Research UK

Your research papers will be:

- available free of charge to the entire biomedical community

- peer reviewed and published immediately upon acceptance

- cited in PubMed and archived on PubMed Central

- yours - you keep the copyright
BioMedcentral 